\title{
Investigation of the critical sources of investment finance in Nigeria: a factor analytical approach
}

\author{
Godwin Chigozie Okpara
}

\author{
Department of Banking and Finance, Abia State University Uturu -Nigeria.
}

\begin{abstract}
The paper aimed at investigating the most critical sources of investment finance in Nigeria. To do this, factor analysis technique and the multiple regression analysis were used as alternate methods. The two techniques were used for the ascertainment of the authenticity or validity of the results. The empirical results from both methods revealed that savings and private sector credits are the most crucial sources of investment finance in Nigeria. In the light of this finding, the researcher recommends that government should set a conducive financial and political atmosphere that will be attractive enough to foreign investors if foreign direct investment and capital market activities should be made good predictors of investment finance in Nigeria.
\end{abstract}

Keywords: Investment Finance, Savings, Private sector credit, Foreign Direct Investment.

\section{INTRODUCTION}

According to Anyanwu (1995) "while progress has been substantial in the study of consumption behaviour, at the micro and macro levels, in time and space, the same is hardly true of investment. Consequently, it has actually been impossible to formulate a model that can explain or predict the behaviour of investment with reasonable degree of accuracy". It is obvious that substantial progress has not been made in the study of investment but that does not preclude the fact that a model of investment can be formulated with reasonable degree of accuracy. In the words of Dornbusch (1981), investment is spending devoted to increasing or maintaining the stock of capital. The stock of capital consists of factories, machines, offices and other durable products used in the process of production. Abajemito, Bamidele, Enendu and Abdullahi (2004) defined investment as both investment in machines and human capital in the form of quality education and training. The Nigerian National Income Accounts define investment along the lines of gross private domestic investment or gross fixed capital formation (GFCF) as consisting of all capital expenditure on building (residential and non residential) land improvements, transport, equipment, breading stock and /or machinery and equipment (Anyanwu, 1995 )

From a microeconomic perspective, investment financing may come from internal sources, such as self-financing or retained earnings, or from external sources such as loans, bonds or equity. From a macroeconomic perspective (i.e. for the economy as a whole), financing may come from domestic or foreign sources, but it is only the foreign sources that create a liability for the economy. A complementary distinction refers to foreign and national savings, the latter of which can be further decomposed into household, business and government savings. From an accounting point of view, the savings generated in the whole economy during a certain period of time must equal total investment (UNCTAD 2009).

In Nigeria, investment expenditure classified by source can be into domestic and foreign segments. At the domestic level, investment can further be divided into public and private sector investment, which is the public and private sector addition to the stock of capital. Foreign investment on the other hand can be sub divided into foreign direct investment (FDI) and portfolio investments. Foreign direct investment is investment in physical productive assets such as machinery, construction, investment, technology, management or marketing expertise by a company incorporated in a foreign country. FDI may be attracted by the opportunity to use local raw materials or employ local labour force. Rates of return, credit ratings and secondary-market prices of sovereign debt, reflecting the opportunities and risks of investing in the country have been recognized as other crucial determinants of capital flows. The major advantages of FDI, whether full or partial are that it brings technology, ideas and access to industrial country markets as well as hard currency, reduces borrower's exposure to changes in foreign interest rates and encourages growth oriented economic liberalization (Essien and Onwioduokit, 1999). While portfolio investment involves investment in equity shares, bonds, debentures of local companies or 
money market instruments of domestic economy by foreign entities. (Wilkinson 2007, Obadan, 2004). Investment is invariably the use of capital for the maintenance of the existing wealth or furtherance of production of wealth in abundance. The total investment that occurs in the economy is called gross investment .The amount necessary for replacement is called the capital consumption allowance and is often referred to as depreciation while the remainder is called net investment. It is net investment that increases the economy's total stock of capital while the replacement investment keeps the existing stock intact by replacing what has been worn out or otherwise used up (Lipsey, 1980).

The domestic formal sources of investment finance for both private and public sectors could be through own savings and borrowing especially from financial institutions. In Nigeria, the financial institutions that are involved in providing investment finance are the deposit money banks (DMB), mortgage institutions, development finance institutions and the non-bank financial institutions like the pension funds, equipment leasing companies, cooperative and thrift societies and so on.

Investment finance could also be sourced externally through borrowing or loan from abroad, receiving grants and gifts, equity participation by foreign entities and through foreign direct investments. Foreign institutions involved in the provision of such investment funds are the multilateral organizations such as the World Bank, international development Association (IDA), African development bank (ADB), United Nations programme (UNDP), Multinationals for direct investment, European union (EU) etc.

\section{LITERATURE REVIEW}

Finance is very crucial to investment (Mckinnon 1973, Shaw, 1973). Financial institutions must pool savings and direct them through viable investment if growth must take place. Credit is the link through which resources are transferred for capital formation. Lynch (1995) contends that the financial sector, which creates these credits, affects not only the quality of investment but also the efficiency of its allocation. UNCTAD (2009) contends that Credit creation by the banking system is particularly important for enterprises, especially new enterprises, which are heavily dependent on borrowing to meet their need for fixed investment and working capital. It added that Credit is created ex nihilo when a commercial bank extends to a firm a loan that can be financed by borrowing from the central bank via the discount window or open market operations, which implies an increase in the money supply. It also noted that in addition to retained profits, credit creation plays an important role in financing productive investment. Odoko, Okafor and Kama (2004) observed that research evidences support the hypothesis that credit flows have a positive and statistically significant effect on private investment.

Foreign investment is also an addition to capital stock of a nation. This source is however very sensitive and therefore volatile as any little instability in the host country can lead to its flight. Nigeria's precarious economic and political climate constituted an inhibition for attracting full potentials from foreign investment. Ebajemito, Bamidele, Enendu and Abdullahi (2004), noted that inspite of vast investment opportunities in agriculture, industry, oil and gas, commerce and infrastructure, to mention a few, very little foreign investment capital was attracted when compared with other countries and regions competing for global investment capital; owing to the unattractiveness of the Nigerian investment climate, characterized by high production costs; inadequate infrastructure; financial sector distress; pervasive corruption,; high rate of crime, spiraling inflation; political instability; and macroeconomic imbalance.

Own savings being the immediate source of fund in investment can neither be overlooked nor overemphasized. Private investment is said to be positively related to the accumulation of real money balances. To stimulate investment, entrepreneurs in the developing countries need to accumulate real money balances before undertaking investment projects given their limited access to credit and equity markets (Oloyede, 1998). It is however the inadequacy of domestic savings that calls for foreign debt financing. Saving by definition is income less consumption. Chenery and Bruno (1962) argued that investment to GDP ratio consistently exceeded the savings gap ratio, implying that domestic saving was insufficient to fund the required investment. This is the saving-GDP model and it points to the need for external finance to supplement domestic resources (Odoko, Okafor and Kama, 2004). Obadan and Odusala (2001) in their research work came out with the result that investment is savings constrained implying that low savings lead to low investment and vice versa in Nigeria.

External borrowing is a supplementary means of obtaining additional resources for the spending programmes of the government. Ndekwu (1983) noted that the borrowing supplements domestic 
savings, credit and investment, and thereby makes domestic spending to be greater than what would otherwise be the case. The borrowing may be used to finance imports, meet balance of payments requirements or to improve the nations external reserves. According to National Planning Commission (2006), capital importation into the economy has been on the increase, growing at an average growth rate of 82 percent since 2002 . The spike in capital importation in 2005 is attributed largely to the banking sector consolidation exercise. The increase in capital importation shows shortage of accumulated savings for any meaningful investment and development.

The contribution of capital market to investment finance in any period is measured in terms of the amount of fresh funds raised through new issues rather than volume of transactions or market capitalization (Ebajemito, Bamidele, Enendu and Abdillahi, 2004). New issues can be through initial public offers, rights offers, bonds and offer for sale. The volume of new issues by companies grows significantly with the passage of time. From the average of 0.30236 billion between 1970 to 1979 , it rose to an average of 0.40257 billion between 1980 and 1989. The figure grew steadily in unit of one till 1995when it recorded the highest unit digit of 7.08 billion owing probably to internationalization of capital market in 1995 but double digited in 1996 from where it grew to 67.3 billion in 2002 . A sharp triple - digit figure of 185 billion in 2003 was due to the issuance of 150.0 billion worth of bonds by the federal government, out of which 75.2 billions was subscribed (Abajemito et al 2004).

\section{MATERIALS AND METHODS}

The data were sourced from the published data of the statistical bulletin of the Central bank of Nigerian. In analyzing the determinant of investment sources, the researcher employs factor analytical tools. Factor analysis is often used in data reduction to identify a small number of factors that explain most of the variance observed in a much larger number of manifest variables. It seeks to collapse the numerous operating variables into fewer dimensions of interrelated attributes called principal components. The mathematical procedure of factor analysis assumes that an $n \times n$ matrix ' $A$ ' has eigenvalues ' $\lambda$ ' if there exists a non-zero vector ' $X$ ', called an eigenvector associated with $\lambda$, for which:

$$
A x=\lambda x
$$

From equation $I$, it follows that the matrix $A-\lambda I$ is singular and therefore that: $(A-\lambda)=0$
Equation 2 is a polynomial equation in $\lambda$ of degree $n$ from which it follows that $A$ is at most $n$ eigenvalues. The polynomial, det $(A-\lambda)$ is called the characteristic polynomial of ' $A$ '. Some roots of this characteristic equation are repeated and we have the algebraic multiplicity of the eigenvalue in the same way as the multiplicity of roots of polynomials. In the event that the multiplicity of an eigenvalue is greater than the dimension of the vector space spanned by its associated eigenvalues, then the matrix is defective.

Solving the eigenvalue problem that is finding eigenvalues and associated eigenvectors is in general best achieved by solving the characteristic equation (Ebiringa, 2009). Factors used as explanatory variables for the determination of investment finance are capital expenditure (Capexpend), savings, foreign direct investment (FDI), private sector credit (Pscredit), New issues (Newissue) and financial deepening (Findeep) representing the state of the financial development.

Table 1: Communalities

\begin{tabular}{|l|l|l|}
\hline & Initial & Extraction \\
\hline Newissue & 1.000 & .853 \\
FDI & 1.000 & .912 \\
Savings & 1.000 & .978 \\
Findeep & 1.000 & .062 \\
Pscredit & 1.000 & .957 \\
Capexpend & 1.000 & .903 \\
\hline
\end{tabular}

Extraction Method: Principal Component Analysis

Empirical Results and Discussions: The estimates of the extent each factor impacts on investment as analyzed using maximum (communalities) likelihood extraction analysis are presented in table 1 of the appendix. The result of the communalities shows that all but financial deepening variable are well and completely fitted with the factor solution and none could be possibly dropped from the analysis. In view of this, the researcher employed the principal component analysis of the extraction method and came out with the result in table 2. The result shows that only two components were extracted under 0.959 eigenvalue minimum. The clustering of the decision factors affecting investment within the two components generated normalized cumulative sums of squared loading of 93.738 percent. This shows that the two decision variables depict about 94 percent of the characteristics of the six isolated factors affecting investment sources in Nigeria. In other words 94 percent of the total variation in the level of investment sources is explained by cumulative effect of the two components extracted. The two components are indicative in the screen plot not shown here. The test of reliability using the chi-square test of KMO and Bartletts Test (see table 3 in the appendix) shows that within zero percent level of maximum error, the predicted level of variance is reliable. 
Am. J. Sci. Ind. Res., 2010, 1(2): 309-313

Table 2: Total Variance Explained

\begin{tabular}{|c|c|c|c|c|c|c|}
\hline \multirow[b]{2}{*}{ Component } & \multicolumn{3}{|c|}{ Initial Eigenvalues } & \multirow[b]{2}{*}{ Total } & \multirow[b]{2}{*}{$\%$ of variance } & \multirow[b]{2}{*}{ Cumulative \% } \\
\hline & Total & $\%$ of variance & Cumulative \% & & & \\
\hline $\begin{array}{l}1 \\
2 \\
3 \\
4 \\
5 \\
6\end{array}$ & $\begin{array}{l}4.665 \\
.959 \\
.360 \\
.010 \\
.004 \\
.002\end{array}$ & $\begin{array}{r}77.747 \\
15.990 \\
5.998 \\
.168 \\
.068 \\
.028\end{array}$ & $\begin{array}{r}77.747 \\
93.738 \\
99.736 \\
99.904 \\
99.972 \\
100.000\end{array}$ & 4.665 & 77.747 & 77.747 \\
\hline
\end{tabular}

Table 3: KMO and Bartlett's Test

\begin{tabular}{|lr|r|} 
Kaiser-Meyer-Olkin & Measure of & \\
Sampling Adequacy & & .733 \\
Bartlett's Test of & Approx. & 531.074 \\
Chi-Square & & 15 \\
Sphericity & df & .000 \\
Sig. & & \\
\hline
\end{tabular}

To identify the variables that form the two principal components, the component matrix is presented in table 4 of the appendix. The table shows the loading of the factors into one principal component under eigenvalue of one, but under eigenvalue of 0.959 , there are two principal components namely savings with a component score of 0.989 and private sector credit with a component score of 0.978. Thus, savings and private sector credit are the most critical investment sources in Nigeria.
Table 4: Component Matrix

\begin{tabular}{|l|c|}
\hline & $\frac{\text { Component }}{1}$ \\
\hline Newissue & .924 \\
FDI & .955 \\
Savings & .989 \\
Findeep & -.248 \\
Pscredit & .978 \\
Capexpend & .950 \\
\hline
\end{tabular}

Extraction Method Principal Component Analysis. a. 1 Components extracted.

The result of the regression analysis used as an alternate method (see table 5 and 6 of the appendix) supported the above result by identifying savings and private sector credits as exerting a positive and significant impact on investment while other factors are insignificant.

Table 5: Coefficientsa

\begin{tabular}{|c|c|c|c|c|c|}
\hline \multirow[t]{2}{*}{ Mode } & \multicolumn{2}{|c|}{ Unstandardized Coefficients } & \multirow{2}{*}{$\begin{array}{c}\begin{array}{c}\text { Standardized } \\
\text { Coefficients }\end{array} \\
\text { Beta }\end{array}$} & \multirow[b]{2}{*}{$\mathbf{t}$} & \multirow[b]{2}{*}{ Sig. } \\
\hline & B & Std. Error & & & \\
\hline $\begin{array}{ll}1 . & \text { (Constant) } \\
\text { Newissue } \\
\text { FDI } \\
\text { Savings } \\
\text { Findeep } \\
\text { Pscredit } \\
\text { Capexpend }\end{array}$ & $\begin{array}{r}33143.177 \\
-400.763 \\
.696 \\
3.318 \\
-1699.196 \\
1.719 \\
.718\end{array}$ & $\begin{array}{r}41508.322 \\
377.115 \\
.445 \\
.344 \\
1459.857 \\
.305 \\
.718\end{array}$ & $\begin{array}{r}-.249 \\
.458 \\
2.702 \\
-.028 \\
-2.253 \\
.304\end{array}$ & $\begin{array}{r}.798 \\
-1.063 \\
1.564 \\
9.658 \\
-1.164 \\
5.644 \\
1.304 \\
\end{array}$ & $\begin{array}{l}.431 \\
.296 \\
.128 \\
.000 \\
.254 \\
.000 \\
.202\end{array}$ \\
\hline
\end{tabular}

a.Dependent Variable: Investment.

Table 6: Model Summary

\begin{tabular}{|c|c|c|c|c|c|c|c|c|c|c|}
\hline \multirow[b]{2}{*}{$\begin{array}{l}\text { Mod } \\
\mathrm{e} \\
1\end{array}$} & \multirow[b]{2}{*}{$\mathrm{R}$} & \multirow[b]{2}{*}{$\begin{array}{l}\mathrm{R} \\
\text { Square }\end{array}$} & \multirow[b]{2}{*}{$\begin{array}{l}\text { Adjusted } \\
\mathrm{R} \\
\text { Square }\end{array}$} & \multirow[b]{2}{*}{$\begin{array}{l}\text { Std. Error of } \\
\text { The Estimate }\end{array}$} & \multicolumn{4}{|c|}{ Change Statistics } & \multirow{2}{*}{$\begin{array}{l}\text { Change } \\
\text { Statistics } \\
\text { Sig. F Change }\end{array}$} & \multirow[b]{2}{*}{$\begin{array}{l}\text { Durbin- } \\
\text { Watson }\end{array}$} \\
\hline & & & & & $\begin{array}{l}\text { R Square } \\
\text { Change }\end{array}$ & F Change & df1 & df2 & & \\
\hline 1 & $\begin{array}{l}992 \\
a\end{array}$ & .986 & .983 & 60297.67764 & .986 & 357.438 & 6 & 30 & .000 & 1.481 \\
\hline
\end{tabular}

a. Predictors (Constant), Capexpend, Findeep, Newissue, Savings, FDI, Pscredit

b. Dependents Variable: Investment

\section{CONCLUSIONS:}

Variables used in this study for determination of the most critical sources of investment finance in Nigeria are capital expenditure of the government, savings, private sector credit, foreign direct investment, New issues and financial deepening which serves as a control variable indicating the financial state or development of the economy. Borrowing is deliberately omitted because borrowing may be used 
to finance imports, meet balance of payments requirements or to improve the nations external reserves. The use of external borrowing for domestic investment is subsumed in the capital expenditure of the government just as the portfolio investment is subsumed in the new issues of the capital market.

The empirical results from both factor analysis method and the regression analysis revealed that savings and private sector credit are most crucial sources of investment finance in Nigeria. The role of savings in particular in investment finance is too important to be reckoned with. The finding corroborates the conclusive statement that firms in Nigeria apportion significant (more) earnings to retention (savings) for the ploughing back and growth of the firm when it experiences surplus earnings. (Okpara, 2010). It also supports the observation and assertion of Odoko, Okoafor and Kama (2004) and UNCTAD (2009) concerning credit. Thus, savings and private sector credits are good predictors of investment in Nigeria. In the light of this finding, the government should therefore create a conducive financial and political environment capable of attracting foreign private investment if foreign direct investment and capital market activities should be made very relevant in supporting investment and economic growth in Nigerians.

\section{REFERENCES}

Anyanwu, J.C. and Oaikhenan H.E. (1995): Modern Macroeconomics Theory and Applications is Nigeria. Joanee Educational Publishers Ltd, Onitshia

Abajemito, J.O. Bamidele A; Enendu C.I; and Abdullahi (2004) Financing Investment for Growth: The Nigerian Experience; In Finance, Investment and Growth in Nigeria. A Central Bank of Nigeria Publication.

Chenery and Bruno (1962): Development Alternatives in An Open Economy: The Case of Isreal. Economic Journal vol.77.

Dornbusch, R. and Fischer, S. (1981): Macro-Economics McGraw-Hill International Book Company, Auckland.

Ebiringa, O.T (2009): Automated Teller Machine and Electronic Payment in System in Nigeria: A Synthesis of the Critical Success Factor. African Journal of Economics and Financial Research Vol.1. No.1
Essien, E.A. and Onwioduokit (1999): Capital Flows to Nigeria: Issues and Determinants. In Central Bank of Nigeria Economic and Financial Review vol. 37 No.1

Lipsey, R.G. (1980) An Introduction to Positive Economics English Language Book Society ELBS, Kingston.

Mckinnon, R.I. (1973) Money and Capital in Economic Development. Brooklyn Institution. National Planning Commission (2006) Economic Performance Review NPC Abuja.

Ndekwu, E.C. (1983) Government Borrowing, Money Supply and Monetary Policy in Nigeria. Nigerian Institute of Social and Economic Research, Ibadan.

Obadan, M.I. and Odusola, A.F. (2001): Savings, Investment and Growth Patterns in Developed and Developing Countries. National Centre for Economic, Management and Administration Monograph Series No.1 Secreprint Nigeria, Ltd. Ibadan.

Obadan,M. I. (2004) Foreign Capital Flows and External Debt perspectives Countries Nigeria and The LDCs Group, Ibadan University Printer,Nigeria.

Odoko, F.O., Okoafor, B. and Kama U. (2004) Finance, Investment and Growth in Nigeria: Conceptual and Analytical Framework. In Finance, Investment and Growth in Nigeria. A Central Bank of Nigeria

Publication

Oloyede, A. (1998) The Financial System's Role in Resource Mobilization and Investment: An Analysis of Financial Deepening in Nigeria's Financial Sector. In the Dynamics of Managing the Nigerian Financial System in the $21^{\text {st }}$ Century. A Publication of the Central Bank of Nigeria.

Okpara, G.C (2010) A Diagnosis of the Determinant of Dividend Pay-out Policy in Nigeria: A Factor Analytical Approach. American Journal of Scientific Research Issue 8: 57-67.

Shaw, E. (1973) Financial Deepening in Economic Development. Oxford University.

UNCTAD 2008 Domestic Sources of Finance and Investment in Productive Capacity.S United Nations Conference on Trade and Development Geneva

Wilkinson, C. (2007) Academic's Dictionary of Banking EPP Books Services Nigeria Ltd. 